\title{
PENGARUH GAYA KEPEMIMPINAN TERHADAP SEMANGAT KERJA PNS PADA KEMENTERIAN AGAMA KABUPATEN BOGOR
}

\author{
Angka Priatna \\ Dosen Tetap Fakultas Ekonomi Universitas Pakuan \\ Lecturer of Economic Faculty at Pakuan University \\ Fariz Ferdiansyah \\ Mahasiswa Fakultas Ekonomi Universitas Pakuan \\ Student of Economic Faculty at Pakuan University
}

\begin{abstract}
ABSTRAK
Salah satu unsur penting kepemimpinan dalam kaitannya terhadap semangat kerja adalah gaya kepemimpinan. Gaya kepemimpinan adalah cara seorang pemimpin mempengaruhi perilaku bawahan, agar mau bekerja sama dan bekerja secara produktif untuk mencapai tujuan organisasi. Semangat kerja yang tinggi bisa dilihat dari jumlah presensi, kerja sama yang baik, dan hubungan yang harmonis. Metode analisis yang digunakan adalah Analisis koefisien korelasi Rank Spearman, Analisis Koefisien Determinasi, dan Uji Hipotesis Koefisien Korelasi. Berdasarkan perhitungan koefisien korelasi rank spearman didapatkan hasil 0,867 angka tersebut menunjukan bahwa gaya kepemimpinan mempunyai hubungan yang sangat kuat dengan semangat kerja pada Kementerian Agama Kabupaten Bogor. Berdasarkan perhitungan Koefisien determinasi didapatkan hasil $75,16 \%$ yang berarti gaya kepemimpinan dapat mempengaruhi turun naiknya semangat kerja dan sisanya sebesar 24,84\% dipengaruhi faktor lain. Berdasarkan uji hipotesis yang dihitung, t-hitung $(12,03)>t$-tabel $(1,2996)$, maka tolak Ho dan terima Ha sehingga terdapat hubungan positif antara gaya kepemimpinan dengan semangat kerja.
\end{abstract}

Kata Kunci: Pendelegasian Wewenang, Tanggung Jawab, Presensi, Kerja Sama, Hubungan yang Harmonis

\begin{abstract}
One important element of leadership in relation to the morale is leadership style. Leadership style is the way a leader influences the behavior of subordinates, to cooperate and work productively to achieve organizational goals. High moral can be seen from the amount of presence, good cooperation and harmonious relationship. The analytical method used is the analysis of Spearman Rank correlation coefficient, Coefficient of Determination Analysis and Hypothesis Testing Correlation Coefficient. Based on the calculation of Spearman rank correlation coefficient 0.867 results obtained these figures show that the leadership style has a very strong relationship with moral in the Ministry of Religion Bogor Regency. The coefficient of determination based on the calculation results obtained $75.16 \%$, which means that the leadership style can affect moral downs and the remaining $24.84 \%$ influenced by other factors. Calculated based on the hypothesis test, t-test (12.03) > t-table (1.2996), then reject Ho and accept Ha so that there is a positive relationship between leadership style with morale.
\end{abstract}

Keywords: Delegation of Authority, Responsibility, Presence, Cooperation, Harmonious Relationships

\section{Pendahuluan}

Setiap organisasi memiliki berbagai sasaran yang akan diraih guna mencapai tujuan organisasi. Sasaransasaran itu akan dapat tercapai melalui aktivitas-aktivitas yang dilakukan dengan cara melibatkan aspek-aspek sumber daya yang terdapat dalam organisasi tersebut. Misalnya modal, mesin, atau peralatan, sumber daya manusia, dan sebagainya, diantara aspek tersebut yang paling penting adalah aspek sumber daya manusia. Begitu pentingnya sumber daya manusia maka organisasi perlu memberikan semangat kerja kepada pegawai, sehingga dapat 
merangsang pegawai untuk dapat bekerja dengan giat dan dapat meyelesaikan pekerjaan tepat waktu.

Kondisi ini sangat dipengaruhi oleh peran seorang pemimpin dalam organisasi. Salah satu peran yang penting seorang pemimpin adalah membuat para pegawainya mempunyai semangat kerja yang tinggi. Tujuan tersebut dapat terwujud jika orang-orang yang ada didalamnya mampu bekerja sama dengan orang lain, dengan koordinasi seorang pemimpin yang memiliki berbagai kemampuan untuk mengarahkan anggotanya. Salah satu unsur penting kepemimpinan dalam kaitannya terhadap semangat kerja karyawan adalah gaya kepemimpinan.

Gaya kepemimpinan yang efektif akan memberikan kontribusi besar terhadap semangat kerja pegawai, sebaliknya gaya kepemimpinan yang tidak efektif dapat menghambat semangat kerja pegawai. Indikasi semangat kerja bisa dilihat dari presensi, kerja sama, hubungan yang harmonis.

Penulis akan membahas mengenai gaya kepemimpinan delegatif di Kantor Kementerian Agama Kabupaten Bogor. Penulis menemukan bahwa semangat kerja pegawai di kantor tersebut masih kurang optimal. Hal ini terlihat dari masih rendahnya tingkat presensi, kerjasama, dan tanggung jawab pegawai. Mengingat pentingnya masalah tersebut, maka penulis tertarik untuk melakukan penelitian apakah ada masalah pada gaya kepemimpinan yang diterapkan oleh kepala kantor Kementerian Agama Kabupaten Bogor. Adapun tujuan dari penelitian yang penulis lakukan adalah sebagai berikut: 1) Untuk mengetahui gaya kepemimpinan delegatif yang diterapkan pada Kementerian Agama Kabupaten Bogor; 2) Untuk mengetahui tingkat semangat kerja pada
Kementerian Agama Kabupaten Bogor; 3) Untuk mengetahui pengaruh gaya kepemimpinan terhadap semangat kerja PNS pada Kementerian Agama Kabupaten Bogor.

\section{Metode Penelitian}

1. Menghitung dengan menggunakan rumus Koefisien Korelasi Rank Spearman:

$$
\mathrm{r}_{\mathrm{s}}=1-\frac{6 \sum d i^{2}}{n\left(n^{2}-1\right)}
$$

Keterangan :

$\mathrm{r}_{\mathrm{s}} \quad=$ Koefisien Korelasi Rank Spearman

$\mathrm{n}=$ Ukuran Sampel

$d i^{2}=$ Selisih dari pasangan rank ke-i

2. Menghitung dengan menggunakan rumus Koefisien Determinasi:

$$
\mathrm{KD}=\mathrm{r}_{\mathrm{s}} \times 100 \%
$$

Keterangan :

$$
\begin{aligned}
& \mathrm{KD}=\text { Koefisien Determinasi } \\
& \mathrm{r}_{\mathrm{s}}=\text { Koefisien Korelasi }
\end{aligned}
$$

3. Menghitung dengan menggunakan Uji Hipotesis Koefisien Korelasi:

Keterangan :

$$
t_{h}=r_{s} \sqrt{\frac{n-2}{1-r_{s}^{2}}}
$$

$\mathrm{t}_{\mathrm{h}} \quad=\mathrm{t}$ hitung

$\mathrm{r}_{\mathrm{s}}=$ Koefisien korelasi rank spearman

$\mathrm{n} \quad=$ jumlah sample

III. Hasil dan Pembahasan

3.1 Pengaruh Gaya Kepemimpinan Terhadap Semangat Kerja PNS pada Kementerian Agama Kabupaten Bogor 
Tabel 3.1.

Koefisien Korelasi Antara Gaya Kepemimpinan (X) dan Semangat Kerja (Y) Koefisien Correlation Between Leadership Style $(X)$ and Work Spirit $(Y)$

\begin{tabular}{|c|c|c|c|c|c|c|}
\hline No. & $(\mathrm{X})$ & (Y) & $\mathrm{Rx}$ & Ry & $d i$ & $d i^{2}$ \\
\hline 1 & 33 & 46 & 30 & 45,5 & $-15,5$ & 240,25 \\
\hline 2 & 33 & 44 & 30 & 33 & -3 & 9 \\
\hline 3 & 36 & 46 & 49 & 45,5 & 3,5 & 12,25 \\
\hline 4 & 34 & 45 & 42 & 40,5 & 1,5 & 2,25 \\
\hline 5 & 28 & 39 & 1 & 1 & 0 & 0 \\
\hline 6 & 32 & 43 & 18 & 21 & -3 & 9 \\
\hline 7 & 32 & 44 & 18 & 33 & -15 & 225 \\
\hline 8 & 35 & 44 & 46 & 33 & 13 & 169 \\
\hline 9 & 35 & 45 & 46 & 40,5 & 5,5 & 30,25 \\
\hline 10 & 34 & 46 & 42 & 45,5 & $-3,5$ & 12,25 \\
\hline 11 & 33 & 44 & 30 & 33 & -3 & 9 \\
\hline 12 & 30 & 40 & 5 & 3 & 2 & 4 \\
\hline 13 & 33 & 41 & 30 & 6,5 & 23,5 & 552,25 \\
\hline 14 & 31 & 42 & 11,5 & 11,5 & 0 & 0 \\
\hline 15 & 33 & 43 & 30 & 21 & 9 & 81 \\
\hline 16 & 30 & 43 & 5 & 21 & -16 & 256 \\
\hline 17 & 33 & 44 & 30 & 33 & -3 & 9 \\
\hline 18 & 36 & 46 & 49 & 45,5 & 3,5 & 12,25 \\
\hline 19 & 33 & 44 & 30 & 33 & -3 & 9 \\
\hline 20 & 35 & 47 & 49 & 45,5 & 3,5 & 12,25 \\
\hline 21 & 30 & 40 & 5 & 3 & 2 & 4 \\
\hline 22 & 32 & 43 & 18 & 21 & -3 & 9 \\
\hline 23 & 30 & 41 & 5 & 6,5 & $-1,5$ & 2,25 \\
\hline 24 & 31 & 43 & 11,5 & 21 & $-9,5$ & 90,25 \\
\hline 25 & 33 & 44 & 30 & 33 & -3 & 9 \\
\hline 26 & 34 & 47 & 42 & 45,5 & $-3,5$ & 12,25 \\
\hline 27 & 33 & 44 & 30 & 33 & -3 & 9 \\
\hline 28 & 30 & 42 & 5 & 11,5 & $-6,5$ & 42,25 \\
\hline 29 & 38 & 40 & 1 & 3 & -2 & 4 \\
\hline 30 & 33 & 43 & 30 & 21 & 9 & 81 \\
\hline 31 & 30 & 42 & 5 & 11,5 & $-6,5$ & 42,25 \\
\hline 32 & 36 & 47 & 49 & 45,5 & 3,5 & 12,25 \\
\hline 33 & 33 & 44 & 30 & 33 & -3 & 9 \\
\hline 34 & 31 & 42 & 11,5 & 11,5 & 0 & 0 \\
\hline 35 & 33 & 44 & 30 & 33 & -3 & 9 \\
\hline 36 & 31 & 43 & 11,5 & 21 & $-9,5$ & 90,25 \\
\hline 37 & 31 & 42 & 11,5 & 11,5 & 0 & 0 \\
\hline 38 & 33 & 43 & 30 & 21 & 9 & 81 \\
\hline 39 & 32 & 43 & 18 & 21 & -3 & 9 \\
\hline
\end{tabular}




\begin{tabular}{|c|c|c|c|c|c|c|}
40 & 34 & 45 & 42 & 40,5 & 1,5 & 2,25 \\
\hline 41 & 33 & 43 & 30 & 21 & 9 & 81 \\
\hline 42 & 32 & 42 & 18 & 11,5 & 6,5 & 42,25 \\
\hline 43 & 31 & 43 & 11,5 & 21 & $-9,5$ & 90,25 \\
\hline 44 & 33 & 44 & 30 & 33 & -3 & 9 \\
\hline 45 & 34 & 45 & 42 & 40,5 & 1,5 & 2,25 \\
\hline 46 & 33 & 46 & 30 & 45,5 & $-15,5$ & 240,25 \\
\hline 47 & 33 & 43 & 30 & 21 & 9 & 81 \\
\hline 48 & 32 & 42 & 18 & 11,5 & 6,5 & 42,25 \\
\hline 49 & 32 & 43 & 18 & 21 & -3 & 9 \\
\hline 50 & 30 & 41 & 5 & 6,5 & $-1,5$ & 2,25 \\
\hline Jumlah & 1630 & 2170 & & & & 2771,5 \\
\hline
\end{tabular}

Sumber: Data Diolah

\section{Analisis Koefisien Korelasi Rank Spearman}

$$
\begin{aligned}
& \mathrm{r}_{\mathrm{s}}=1-\frac{6 \sum d i^{2}}{\mathrm{n}\left(\mathrm{n}^{2}-1\right)} \\
& \mathrm{r}_{\mathrm{s}}=1-\frac{6.2771,5}{50\left(50^{2}-1\right)} \\
& \mathrm{r}_{\mathrm{s}}=1-\frac{16629}{124950} \\
& \mathrm{r}_{\mathrm{s}}=1-0,133 \\
& \mathrm{r}_{\mathrm{s}}=0,867
\end{aligned}
$$

Berdasarkan hasil perhitungan diatas di peroleh nilai $r_{s}$ sebesar 0,867 artinya korelasi yang positif antara gaya kepemimpinan dengan semangat kerja.

\section{Analisis Koefisien Determinasi}

Untuk mengetahui seberapa besar kontribusi variabel gaya kepemimpinan terhadap semangat kerja, maka digunakan rumus koefisien determinasi : $\mathrm{KD}=\mathrm{r}_{\mathrm{s}}^{2} \times 100 \%$. Dari rumus tersebut diperoleh hasil sebagai berikut: $\mathrm{KD}=$ $0,867^{2} \times 100 \%=75,16 \%$

Berdasarkan perhitungan diatas, penulis menyimpulkan bahwa gaya kepemimpinan dapat mempengaruhi turun naiknya semangat kerja sebesar $75,16 \%$ dan sisanya sebesar $24,84 \%$ dipengaruhi faktor lain.

\section{Uji Hipotesis Koefisien Korelasi}

Uji hipotesis dilakukan untuk menguji apakah hipotesis yang dibuat dapat diterima atau tidak. Adapun hipotesisnya adalah :

Ho : $\rho=0$, tidak ada hubungan antara gaya kepemimpinan dan semangat kerja.

Ha : $\quad \rho>0$, terdapat hubungan positif antara gaya kepemimpinan dan semangat kerja.

Uji statistiknya adalah:

$$
\begin{aligned}
& \mathrm{t}_{\mathrm{h}}=r_{s} \sqrt{\frac{n-2}{1-r s^{2}}} \\
& \mathrm{t}_{\mathrm{h}}=0,867 \sqrt{\frac{50-2}{1-0,867^{2}}} \\
& \mathrm{t}_{\mathrm{h}}=0,867 \sqrt{\frac{48}{0,249}} \\
& \mathrm{t}_{\mathrm{h}}=0,867 \sqrt{192,77} \\
& \mathrm{t}_{\mathrm{h}}=0,33.13,88 \\
& \mathrm{t}_{\mathrm{h}}=12,03
\end{aligned}
$$

Tolak Ho jika t-hitung > t-tabel. Untuk mendapatkan nilai t-tabel digunakan tarif nyata $10 \%$ dan $\mathrm{df}=(50-$ 2) $=48$, maka, t-tabelnya adalah 1,2996. Dengan demikian t-hitung $(12,03)>\mathrm{t}$ tabel (1,2996), artinya terdapat 
hubungan positif antara gaya kepemimpinan dengan semangat kerja.

\section{Kesimpulan}

Dari hasil penelitian yang telah dilakukan pada Kementerian Agama Kabupaten Bogor, serta hasil dari pembahasan mengenai Pengaruh Gaya Kepemimpinan Terhadap Semangat Kerja, maka penulis mengambil suatu kesimpulan sebagai berikut:

1. Gaya kepemimpinan delegatif yang diterapkan pada Kementerian Agama Kabupaten Bogor sudah baik, hal ini bisa dilihat dari skala kuesioner yang memperlihatkan para pegawai setuju dengan diterapkannya gaya kepemimpinan delegatif.

2. Semangat kerja pada Kementerian Agama Kabupaten Bogor sudah tinggi, hal ini bisa dilihat dari skala kuesioner yang memperlihatkan para pegawai memiliki semangat kerja yang tinggi.

3. Tingkat hubungan antara gaya kepemimpinan dengan semangat kerja pegawai pada Kementerian Agama Kabupaten Bogor memiliki hubungan yang sangat kuat dan positif. Artinya, semakin tepat gaya kepemimpinan yang diterapkan, maka semangat kerja di Kementerian Agama Kabupaten Bogor akan meningkat.

\section{Daftar Pustaka}

Andrew, Sudhir. 2009. Human Resource Management, Tata McGraw-Hill, United State of America.

Azwar, Saifuddin. 2002. Penyusunan Skala Psikologi. Pustaka Pelajar. Yogyakarta

Byars, Lloyd L., and Leslie Rue. 2000. Human Resource Management.
Sixth Edition, Irwin McGraw-Hill, United State of America.

Habsari, Ari Retno. 2008. Terobosan Kepemimpinan, Media Pertisindo, Yogyakarta.

Hasibuan, Malayu. S.P. 2007. Manajemen Sumber Daya Manusia. PT Bumi Aksara, Jakarta.

Husein, Umar. 2005. Riset Sumber Daya Manusia Dalam Organisasi. Gramedia Pustaka Utama, Jakarta.

Harris, O. Jeff., and Sandra, J. Hartman. 2002. Organizational Behaivor. Second Edition, Binghamton, NY.

Mayer, Paul J. 2008. 5 Pilar Kepemimpinan. Nafiri Gabriel, Jakarta.

Oei, Istijanto. 2008. Riset Sumber Daya Manusia. Gramedia Pustaka Utama, Jakarta.

Siswanto, H.B. 2007. Pengantar Manajemen. Edisi 3, PT. Bumi Aksara, Jakarta.

Stoner, James A.F, R. Edward Freeman, Daniel R. Gilbert Jr. 1996. Manajemen. Alih Bahasa: Alexander Sindoro. PT Bhuana Ilmu Populer.

Sugiyono. 2010. Statistik Untuk Penelitian. Alfabeta: Bandung.

Sumarsono, HM. Sonny. 2004. Metode Riset Sumber Daya Manusia. Graha Ilmu, Yogyakarta.

Sutrisno, Edy. 2009. Manajemen Sumber Daya Manusia. Edisi Pertama, Kencana, Jakarta.

Suwatno dan Doni Juni Priansa. 2011. Manajemen SDM Dalam Organisasi Publik dan Bisnis, Alfabeta, Bandung.

Tohardi, Ahmad. 2002. Pemahaman Praktis Manajemen Sumber Daya Manusia, Mandar Maju, Bandung.

Van Wart, Montgomery. 2011. Dynamic Of Leadhership in Public Service, Theory and Practice. Second Edition, New York: M.E. Sharepe Inc. 
Van Wart, Montgomery. 2012.

Organizations. Second Edition, Leadhership In Public New York: M.E. Sharepe Inc. 